\title{
Integrating Herbicide Programs with Harvest Weed Seed Control and Other Fall Management Practices for the Control of Glyphosate-Resistant Palmer Amaranth (Amaranthus palmeri)
}

\begin{abstract}
Jason K. Norsworthy, Nicholas E. Korres, Michael J. Walsh, and Stephen B. Powles*
A large-plot field experiment was conducted at Keiser, AR, from fall of 2010 through fall of 2013 to understand to what extent soybean in-crop herbicide programs and postharvest fall management practices impact Palmer amaranth population density and seed production over three growing seasons. The effect of POST-only (glyphosate-only) or PRE followed by (fb) POST (glyphosate or glufosinate) + residual herbicide treatments were evaluated alone and in combination with postharvest management options of soybean residue spreading or soil incorporation, use of cover crops, windrowing with/without burning, and residue removal. Significant differences were observed between fall management practices on Palmer amaranth population density each fall. The use of cover crops and residue collection and removal $\mathrm{fb}$ the incorporation of crop residues into soil during the formation of beds were the most effective practices in reducing Palmer amaranth population. In contrast, the effects of fall management practices on Palmer amaranth seed production were inconsistent among years. The inclusion of a PRE herbicide application into the herbicide program significantly reduced Palmer amaranth population density and subsequent seed production each year when compared to the glyphosate-only program. Additionally, the glufosinate-containing residual program was superior to the glyphosate-containing residual program in reducing Palmer amaranth seed production. PRE $\mathrm{fb}$ POST herbicides resulted in significant decreases in the Palmer amaranth population density and seed production compared to POST application of glyphosate alone for all fall management practices, including the no-till practice. This study demonstrated that crop residue management such as chaff removal from the field, the use of cover crops, or seed incorporation during bed formation in combination with an effective PRE plus POST residual herbicide program is important for optimizing in-season management of Palmer amaranth and subsequently reducing the population density, which has a profound impact on lessening the risk for herbicide resistance and the consistency and effectiveness of future weed management efforts.
\end{abstract}

Nomenclature: Glufosinate; glyphosate; Palmer amaranth, Amaranthus palmeri S. Wats.; soybean, Glycine max (L.) Merr.

Key words: Cover crops, crop residue, fall management, glufosinate, glyphosate, harvest weed seed control, Palmer amaranth, seed production.

Palmer amaranth is one of the most problematic weeds in soybean, cotton (Gossypium hirsutum L.), and corn (Zea mays L.) in the southern United States (Bryson and Hanks 2006; Massinga et al. 2001; Rankins Jr et al. 2005; Riar et al. 2013a,b). This species' highly competitive ability causes substantial yield losses in these crops (Massinga et al. 2001; Morgan et al. 2001; Rowland et al. 1999). Additionally, its ability to establish large seedbanks

\footnotetext{
DOI: $10.1614 /$ WS-D-15-00210.1

* First and second authors: Professor and Post-Doctoral Research Associate, University of Arkansas, Department of Crop, Soil, and Environmental Sciences, 1366 West Altheimer Drive, Fayetteville, 72704 AR; third and fourth authors: Senior Research Fellow and Winthrop Professor, Australian Herbicide Resistance Initiative (AHRI), School of Plant Biology, University of Western Australia, Perth WA 6009, Australia. Corresponding author's E-mail: korres@uark.edu; nkorres@yahoo.co.uk
}

through prolific seed production and extended germination window (Ward et al. 2013) ensures persistence in crop production systems (Sparks et al. 2003). Species like Palmer amaranth with biological attributes such as these mentioned above and the ability to evolve resistance to numerous herbicides have led to implementing a zero-tolerance seed production policy (Crow et al. 2015; Norsworthy et al. 2014).

Preventing weed seed inputs to the soil seedbank is an effective means of reducing the impact of weeds on subsequent crops while prolonging the efficacy of herbicide-based weed management programs (Walsh et al. 2013). Intensive tillage, stubble burning, crop desiccation, and windrowing using a chute mounted to the rear of the harvester to concentrate the straw and chaff residues into a narrow strip, weed seed collection at harvest using 
chaff carts or baling systems, cover crops, and herbicide programs are some of the methods used for preventing the influx of weed seeds into the soil seedbank (Chauhan and Abugho 2013; Devenish and Leaver 2000; Fogelfors 1982; Storrie 2014; Walsh and Powles 2004). The at-harvest management of weed seed bearing crop residues has been reported as an effective method in reducing seed return into the weed seedbank (Norsworthy et al. 2012). More particularly, Walsh et al. (2013) reported that the collection of chaff during wheat (Triticum aestivum L.) crop harvest allowed the removal of 75 to $85 \%$ of ryegrass (Lolium spp.) seed and 70 to $80 \%$ of wild radish (Raphanus raphanistrum L.) seed. Additionally, Shirtliffe and Entz (2005) reported that the chaff fraction of the debris ejected from the harvester during wheat harvest in Canada contained about $74 \%$ of the wild oat (Avena fatua L.) seed. High proportions of total seed production are retained at wheat crop maturity for the dominant weeds of Australian cropping systems, particularly annual ryegrass (85\%), wild radish $(99 \%)$, brome grass $(77 \%)$, and wild oat $(84 \%)$, clearly identifying the potential for targeting these species during harvest (Walsh and Powles 2004; Walsh and Newman 2007). Similarly, the potential efficacy of harvest weed seed control (HWSC) tactics for Palmer amaranth appear promising since most seed (99\%) are retained at soybean crop maturity (Schwartz et al. 2016).

The use of mulches as an important agronomic tool serves many purposes including, enhancing plant growth by reducing soil moisture evaporation and increased water infiltration (Watson 1988) as well as through weed suppression (Liebl et al. 1992; Skroch et al. 1992). In regards to the latter, the integration of cover crops into cropping systems can be an effective fall management strategy for suppressing weeds (Chauhan and Abugho 2013) through reductions in weed biomass (Korres and Norsworthy 2015) and consequently reproductive capacity (Korres and Froud-Williams 2002). Winter rye (Secale cereale L.) has been reported as a successful cover crop for weed suppression by decreasing weed seed germination and delaying seedling emergence due to high amounts of biomass producing a dense groundcover (Schomberg et al. 2006). The introduction of additional weed management practices will increase production costs, but these costs are insignificant when compared to the cost of losing highly effective herbicides due to resistance (Storrie 2014).
The evolution of herbicide resistance in Palmer amaranth in combination with its potential for substantial crop yield reductions (Klingaman and Oliver 1994; Norsworthy et al. 2014) necessitates the combination of control methods for this weed. Use of diversified methods that target weed seed, preventing inputs to the seedbank, in combination with PRE and POST herbicides can potentially reduce Palmer amaranth infestations to acceptably low plant densities. However, there is very little information on the impact of HWSC and mulching practices alone and in combination with herbicide programs on the population dynamics of Palmer amaranth. The objective of this research was to evaluate the effects of soybean residue management practices in combination with different herbicide regimes on Palmer amaranth population density and seed production.

\section{Materials and Methods}

A field experiment was conducted from fall 2010 through spring 2014 at Keiser, AR, on a Sharkey clay soil. The experiment occupied a site where glyphosate-resistant soybean was grown commercially in 2009 and 2010. At soybean maturity in 2010, the field contained a dense uniform population of approximately 5 to 10 plants $\mathrm{m}^{-2}$ of glyphosate-resistant Palmer amaranth.

A randomized block design with three replications was arranged as a split plot with fall management treatments as main plots and herbicide treatments as sub-subplots. The whole-plot factor was soybean plots $24 \mathrm{~m}$ wide by $64 \mathrm{~m}$ in length. Main plots contained 24 soybean rows with a $1-\mathrm{m}$ spacing between rows on raised beds. The fall management strategies were evaluated as main plots and included: (1) no-till: standard practice where plots were harvested (Case IH 2388 Axial-Flow, Case IH, Racine, WI) and soybean residues spread and retained without fall tillage; (2) fall tillage: raised beds reformed immediately following harvest with normal spread of soybean residues; (3) rye cover crop: 'Wrenz' rye drill seeded in 19-cm-wide rows at $90 \mathrm{~kg} \mathrm{ha}{ }^{-1}$; glyphosate at $870 \mathrm{~g} \mathrm{ae} \mathrm{ha}^{-1}$ (Roundup PowerMax, Monsanto Company, St. Louis, IL) was applied as a burndown treatment prior to soybean planting; (4) narrow-windrowing with burning: harvest residues concentrated into narrow $(500 \mathrm{~mm})$ windrow using chute mounted to rear of harvester; (5) narrow-windrowing without burning: narrow windrow formed but not burned; and (6) residue collection and removal: all residue 
Table 1. Schedule of field operations performed during 3-yr experimentation evaluating the impact of fall management programs following soybean harvest and herbicide programs in soybean on Palmer amaranth population density and seed production.

\begin{tabular}{|c|c|c|c|}
\hline \multirow[b]{2}{*}{ Operations } & \multicolumn{3}{|c|}{ Experimental year } \\
\hline & Fall 2010-Fall 2011 & Fall 2011-Fall 2012 & Fall 2012-Fall 2013 \\
\hline Rye seeding $^{a}$ & October 29, 2010 & November 3, 2011 & November 2, 2012 \\
\hline Soybean seedbed preparation & None ${ }^{b}$ & April 2, 2012 & None \\
\hline Preplant application & May 3, 2011 & April 27, 2012 & May 24, 2013 \\
\hline Soybean planting ${ }^{\mathrm{c}, \mathrm{d}}$ & May 18, 2011 & May 15, 2012 & June 14, 2013 \\
\hline PRE application ${ }^{\mathrm{d}}$ & May 19, 2011 & May 16, 2012 & June 15, 2013 \\
\hline \multicolumn{4}{|l|}{ POST applications } \\
\hline V2 & June 2, 2011 & June 6,2012 & July 2, 2013 \\
\hline V7 & June 29, 2011 & June 29, 2012 & July $19,2013^{\mathrm{e}}$ \\
\hline Soybean harvest & November 1, 2011 & November 1, 2012 & October 25, 2013 \\
\hline \multicolumn{4}{|c|}{${ }^{a}$ Rye was also sown on October 28, 2013.} \\
\hline \multicolumn{4}{|c|}{ beds from the previous soybean crop were used in 2011 and 2012; hence, the test site was not rebedded prior to planting soybean } \\
\hline \multirow{2}{*}{\multicolumn{4}{|c|}{$\begin{array}{l}{ }^{c} \text { Cultivars used were } 4128 \text { LL and AG } 5605 \text { RR in 2011, Halo 4:94LL and AG 4703RR in 2012, and HBK } 4950 \text { and AG } 5233 \text { in } \\
2013 .\end{array}$}} \\
\hline & & & \\
\hline \multicolumn{4}{|c|}{${ }^{\mathrm{d}}$ Paraquat was applied to the entire test area the day of soybean planting. } \\
\hline \multicolumn{4}{|c|}{$\begin{array}{l}{ }^{\mathrm{e}} \text { Rainfall delayed the ground application of treatments at the } \mathrm{V} 7 \text { timing. Applications were actually made to soybean at the R1/R2 } \\
\text { growth stage. The glyphosate application was broadcast, whereas glufosinate was applied only to the row middle under hoods. }\end{array}$} \\
\hline
\end{tabular}

caught during harvest and removed from field. The subplots ( 8 rows by $64 \mathrm{~m}$ ) consisted of three herbicide treatments: (1) glyphosate at $870 \mathrm{~g} \mathrm{ha}^{-1}$ at V2 soybean $\mathrm{fb}$ glyphosate at $870 \mathrm{~g} \mathrm{ha}^{-\mathrm{P}}$ at V7 soybean; (2) flumioxazin (Valor, Valent USA Corporation, Walnut Creek, CA) at $71 \mathrm{~g}$ ai ha ${ }^{-1}$ PRE fb glyphosate at $870 \mathrm{~g} \mathrm{ha}^{-1}+$ a premix of $S$ metolachlor at $1,215 \mathrm{~g}$ ai ha ${ }^{-1}$ and fomesafen at 266 $\mathrm{g}$ ai ha ${ }^{-1}$ (Prefix, Syngenta Crop Protection, Greensboro, NC) at $\mathrm{V} 2 \mathrm{fb}$ glyphosate at $870 \mathrm{~g}$ $\mathrm{ha}^{-1}$ at V7; and (3) flumioxazin at $71 \mathrm{~g} \mathrm{ha}^{-1}$ PRE fb glufosinate (Liberty 280 SL, Bayer CropScience, Research Triangle Park, NC) at $594 \mathrm{~g}$ ai ha ${ }^{-1}+\mathrm{a}$ premix of $S$-metolachlor at $1,215 \mathrm{~g} \mathrm{ha}^{-1}$ and fomesafen at $266 \mathrm{~g} \mathrm{ha}^{-1}$ at V2 $\mathrm{fb}$ glufosinate at 594 $\mathrm{g} \mathrm{ha}^{-1}$ at V7.

The entire field site was treated with glyphosate at $870 \mathrm{~g} \mathrm{ha}^{-1}$ at 2 to 3 wk prior to planting to control the existing weeds and rye cover crop. Immediately after planting, the site was treated with paraquat (Gramoxone, Syngenta Crop Protection, Greensboro, NC) at $700 \mathrm{~g}$ ai ha ${ }^{-1}$. All herbicides were applied with a high clearance sprayer (John Deere 6700) through 11004 AIXR nozzles (TeeJet) on a $48-\mathrm{cm}$ spacing calibrated to deliver $143 \mathrm{~L} \mathrm{ha}^{-1}$ at $12.9 \mathrm{~km} \mathrm{~h}^{-1}$. The trial site was furrow-irrigated as needed throughout the growing season. Soybean was seeded at 30 seed $\mathrm{m}^{-1}$ row each year. All experimental treatments were conducted at Keiser, $A R$, in the same location, for the entire experimen- tal period. The timing of production practices and application dates are summarized in Table 1.

Palmer Amaranth Sampling. Palmer amaranth population density was recorded immediately prior to soybean harvest each year and expressed as plants $\mathrm{m}^{-2}$. Each sampling area was divided into 10 by 10 one square meter sampling units and sampling, using a $1-\mathrm{m}^{2}$ quadrant, was performed based on visual estimations on the Palmer amaranth population density. The law of large numbers (Neyman et al. 1990) was employed to overcome the disproportionality of Palmer amaranth population density across herbicide treatments; e.g., in glyphosate-only program the population density of Palmer amaranth was higher than that in the glufosinate-based program. Hence, $1 \mathrm{~m}^{2}$ was sampled in the glyphosate-only herbicide program, $10 \mathrm{~m}^{2}$ in the glyphosate-based program containing residual herbicides, and $100 \mathrm{~m}^{2}$ in the glufosinate-based program containing residual herbicides. All female plants in these quadrats were cut at ground level prior to soybean harvesting for the determination of Palmer amaranth seed production. Harvested plants were placed in bags and dried in the greenhouse at $32 / 25 \mathrm{C}$ for $2 \mathrm{wk}$ before threshing. Collected seeds were separated from plant tissue using a series of sieves, with the bracts and other plant debris also removed by gently blowing air over the seeds as they were transferred between containers. A minimum of five subsamples of 100 seeds for each subplot was weighed for the determination of seed production, 
Table 2. Effects of fall management practices on log-transformed Palmer amaranth population density (number of plants $\mathrm{m}^{-2}$ ) at soybean harvest averaged across all herbicide treatments.

\begin{tabular}{|c|c|c|c|}
\hline Fall management practice ${ }^{a}$ & 2011 & 2012 & 2013 \\
\hline No till (standard) & 1.15 & 1.37 & 1.35 \\
\hline Fall tillage & 1.09 & 1.06 & 1.27 \\
\hline Rye cover crop & 0.99 & 1.15 & 0.99 \\
\hline Windrowing with burning & 0.72 & 1.14 & 1.19 \\
\hline Windrowing without burning & 1.09 & 1.28 & 1.37 \\
\hline Residue collection and removal & 0.76 & 0.93 & 1.13 \\
\hline Standard error of mean ${ }^{b}$ & 0.053 & 0.045 & 0.059 \\
\hline
\end{tabular}

${ }^{a}$ Refer to the Materials and Methods section for a thorough description of each fall management practice.

b Standard error of mean is for natural log-transformed data $(1+$ plot data $)$ and can be used to assess differences between treatments at statistical level $\alpha=0.01$.

and the total number of seeds produced per plant was extrapolated for the entire sample.

Soybean Yield. At physiological maturity, soybean was harvested (Table 1) using the commercial harvester described previously. All grain from each subplot was weighed and grain yields for each plot were corrected to $13 \%$ moisture using a DickeyJohn mini GAC moisture tester.

Statistical Analysis. A standard least squares model was fitted on the Palmer amaranth seed production data. These were Box-Cox transformed to ensure that the assumptions of normality and homogeneity were satisfied. For the same reason, Palmer amaranth population density data were transformed based on natural logarithms and the same model was applied for their analysis. For reasons of transparency, clarity, and comprehension, both types of data, transformed and untransformed, are presented in this paper. As Palmer amaranth population density and seed production between years were statistically significant different, they were analyzed separately for each year.

Fall management, herbicide regime, and their interactions were treated as fixed effects, while block and block by fall management were treated as random effects. In the case of soybean yield, year by treatment interaction was significantly different $(\alpha=0.05)$; hence, data were separately subjected to ANOVA for each year. JMP Pro 12, SAS statistical software, and Genstat for Windows, Version 10, were used for statistical analyses.

\section{Results and Discussion}

Effects of Fall Management Practices on Palmer Amaranth Density. Palmer amaranth population densities at soybean harvest were significantly reduced $(\alpha=0.01)$ by fall management practices (Table 2). Residue collection and removal, cover crops, and windowing with burning, in that order, were the most effective treatments on Palmer amaranth population density throughout the experimental period. When untransformed Palmer amaranth population densities were expressed as percent reduction of the standard no-till practice, residue collection and removal, for example, resulted in density reductions at 67 and $70 \%$ for the first and second year, respectively, and $41 \%$ in the third year (Table 3 ). The collection and removal of the crop residues along with the weed seeds contained in them can be highly effective in reducing inputs to the weed seedbank and subsequent in-crop weed densities (Shirtliffe and Entz 2005; Walsh and Powles 2007). Concerns regarding possible delays in harvesting operations and consequent extra labor for disposing chaff dumps due to the attached chaff cart to the rear of a harvester have been resolved because of the new modifications of the chaff conveyor design (Walsh et al. 2013).

Reductions of Palmer amaranth density due to rye cover crop were significantly greater $(\alpha=0.01)$ than those recorded for fall tillage and windowing without burning treatments in years 2011 and 2012 (Table 2). In 2013, rye cover crop was the most effective in controlling Palmer amaranth density compared to other fall management treatments (Table 2). Rye cover crop reduced Palmer amaranth density (untransformed data) 57 to $58 \%$ compared to no-till treatments, whereas fall tillage caused a 48 and $57 \%$ reduction in density in the first $2 \mathrm{yr}(2011$ and 2012), respectively. The two cultural practices that have most comprehensively been investigated for managing Palmer amaranth are tillage and the use of cover crops (Ward et al. 2013). The results presented in this study highlight the potential of cereal rye cover crop as a method to reduce the Palmer amaranth population density. Cover crops have been shown to reduce in-crop weed populations (Kruidhof et al. 2008) by interfering with emergence (Chauhan and Abugho 2013; Teasdale and Mohler 1993) and establishment of weed seedlings (Akemo et al. 2000; Teasdale 1996), or through the release of phytotoxic compounds (Blackshaw et al. 2001; Haramoto and Gallandt 2004). Conversely, the effects of fall tillage alone on the Palmer amaranth population density were inconsistent during the experimental period and not statistically different from that recorded under the no-till treatment for the years 2011 and 2013.

Norsworthy et al.: Management practices influence Palmer amaranth dynamics • 543 
Table 3. Influence of fall management practices and herbicide programs in soybean on Palmer amaranth population density in the fall of 2011, 2012, and 2013 at Keiser, AR. Experimental treatments for fall management practices were initiated fall of 2010, and herbicide programs were initiated spring of 2011 with each practice and program applied to the same plots each year through fall of 2013.

\begin{tabular}{|c|c|c|c|c|}
\hline Fall management practice $^{a}$ & Herbicide program $^{\mathrm{b}}$ & 2011 & 2012 & 2013 \\
\hline & & & -plants $\mathrm{m}^{-2}$ & \\
\hline \multirow{3}{*}{ No-till (standard) } & Glyphosate-only & $24.6(3.24)^{\mathrm{c}}$ & $43.2(3.78)^{\mathrm{c}}$ & $34.0(3.50)^{\mathrm{c}}$ \\
\hline & Glyphosate + residuals & $0.21(0.19)$ & $0.35(0.30)$ & $0.73(0.53)$ \\
\hline & Glufosinate + residuals & $0.02(0.02)$ & $0.02(0.02)$ & $0.01(0.001)$ \\
\hline \multirow[t]{3}{*}{ Fall tillage } & Glyphosate-only & $12.0(2.56)$ & $18.7(2.97)$ & $29.3(3.41)$ \\
\hline & Glyphosate + residuals & $0.93(0.66)$ & $0.23(0.20)$ & $0.47(0.39)$ \\
\hline & Glufosinate + residuals & $0.05(0.05)$ & $0.01(0.01)$ & $0.03(0.03)$ \\
\hline \multirow[t]{3}{*}{ Rye cover crop } & Glyphosate-only & $18.3(2.95)$ & $24.9(3.22)$ & $14.12(2.70)$ \\
\hline & Glyphosate + residuals & $0.37(0.31)$ & $0.21(0.19)$ & $0.27(0.23)$ \\
\hline & Glufosinate + residuals & $0.001(0.00)$ & $0.03(0.03)$ & $0.03(0.03)$ \\
\hline \multirow[t]{3}{*}{ Narrow-windrow without burning } & Glyphosate-only & $10.2(2.40)$ & $38.7(3.66)$ & $45.4(3.83)$ \\
\hline & Glyphosate + residuals & $0.21(0.19)$ & $0.21(0.19)$ & $0.32(0.27)$ \\
\hline & Glufosinate + residuals & $0.01(0.01)$ & $0.002(0.00)$ & $0.01(0.01)$ \\
\hline \multirow[t]{3}{*}{ Narrow-windrow with burning } & Glyphosate-only & $6.8(1.99)$ & $27.0(3.30)$ & $36.3(3.62)$ \\
\hline & Glyphosate + residuals & $0.17(0.15)$ & $0.13(0.12)$ & $0.03(0.27)$ \\
\hline & Glufosinate + residuals & $0.02(0.02)$ & $0.007(0.01)$ & $0.00(0.00)$ \\
\hline \multirow{3}{*}{ Residue collection and removal } & Glyphosate-only & $8.0(2.13)$ & $13.0(2.63)$ & $19.8(2.99)$ \\
\hline & Glyphosate + residuals & $0.12(0.12)$ & $0.16(0.15)$ & $0.49(0.40)$ \\
\hline & Glufosinate + residuals & $0.015(0.01)$ & $0.004(0.00)$ & $0.005(0.00)$ \\
\hline Standard error of transformed mean ${ }^{\mathrm{d}}$ & & 0.1 & 0.08 & 0.09 \\
\hline
\end{tabular}

${ }^{a}$ Refer to the Materials and Methods section for a thorough description of each fall management practice.

b The glyphosate-only program consisted of sequential glyphosate applications at $870 \mathrm{~g}^{2} \mathrm{ha}^{-1}$ at V2 and V7 stage of soybean. The glyphosate + residual program consisted of flumioxazin at $71 \mathrm{~g}$ ai ha ${ }^{-1}$ PRE followed by (fb) glyphosate at $870 \mathrm{~g} \mathrm{ha}^{-1}+S-$ metolachlor at $1,215 \mathrm{~g}$ ai ha ${ }^{-1}$ and fomesafen at $266 \mathrm{~g}^{\text {ai ha }}{ }^{-1}$ at V2 stage of soybean fb glyphosate at $870 \mathrm{~g}$ ha ${ }^{-1}$ at V7 stage of soybean. The glufosinate + residual program was the same as the glyphosate + residual program, except both glyphosate applications were replaced with glufosinate at $594 \mathrm{~g}^{\text {ai ha }}{ }^{-1}$.

${ }^{\mathrm{c}}$ Parentheses contain the mean for natural log-transformed data $(1+$ plot data).

d Standard error of mean is for natural log-transformed data $(1+$ plot data $)$ and can be used to assess differences between treatments.

This effect is likely due to the fall tillage being comprised of reforming of the soybean beds rather than more aggressive deep tillage, which has been shown to substantially reduce subsequent Palmer amaranth emergence (DeVore et al. 2013). Similar to our results, Amuri et al. (2010) reported the density of broadleaf weed species was inconsistent between tillage treatments (i.e., no tillage vs. conventional tillage) within seasons for two consecutive years.

Narrow-windrow with burning averaged over herbicide regimes resulted in weed density reductions of 38 and $73 \%$ for 2011 and 2012, respectively, whereas in 2013 there was an increase of Palmer amaranth population density in relation to no-till system by 5\% (Table 3, untransformed data). The low efficacy in 2013 is attributed to the high density of Palmer amaranth found in the glyphosate-only system, which points to fact that fall management strategies alone are not sufficient to consistently lower the Palmer amaranth population. Conversely, there were no Palmer amaranth plants found in the glufosinate+ residual program under no-till practice, a testament to the combined effectiveness of the herbicide program and fall management tactic (Table 3). Overall, narrowwindrowing with burning reduced $(\alpha<0.01)$ Palmer amaranth population densities in comparison to narrow-windrow without burning each year, except 2013. The effectiveness of narrow-windrow with burning is governed by the operational conditions that affect the amount of weed seed captured and accumulated in the windrow by the swathing and harvest operation (Kleemann et al., undated). It is unknown as to whether the air stream from the harvester deposits a portion of the smallsized Palmer amaranth seed outside of the narrow windrow formed during the harvest operation.

\section{Effects of Herbicide Application on Palmer Amaranth Density and Seed Production. Initial} infestations and successive flushes of emerging weeds during the growing season can be successfully controlled by the application of glyphosate (Reed et 

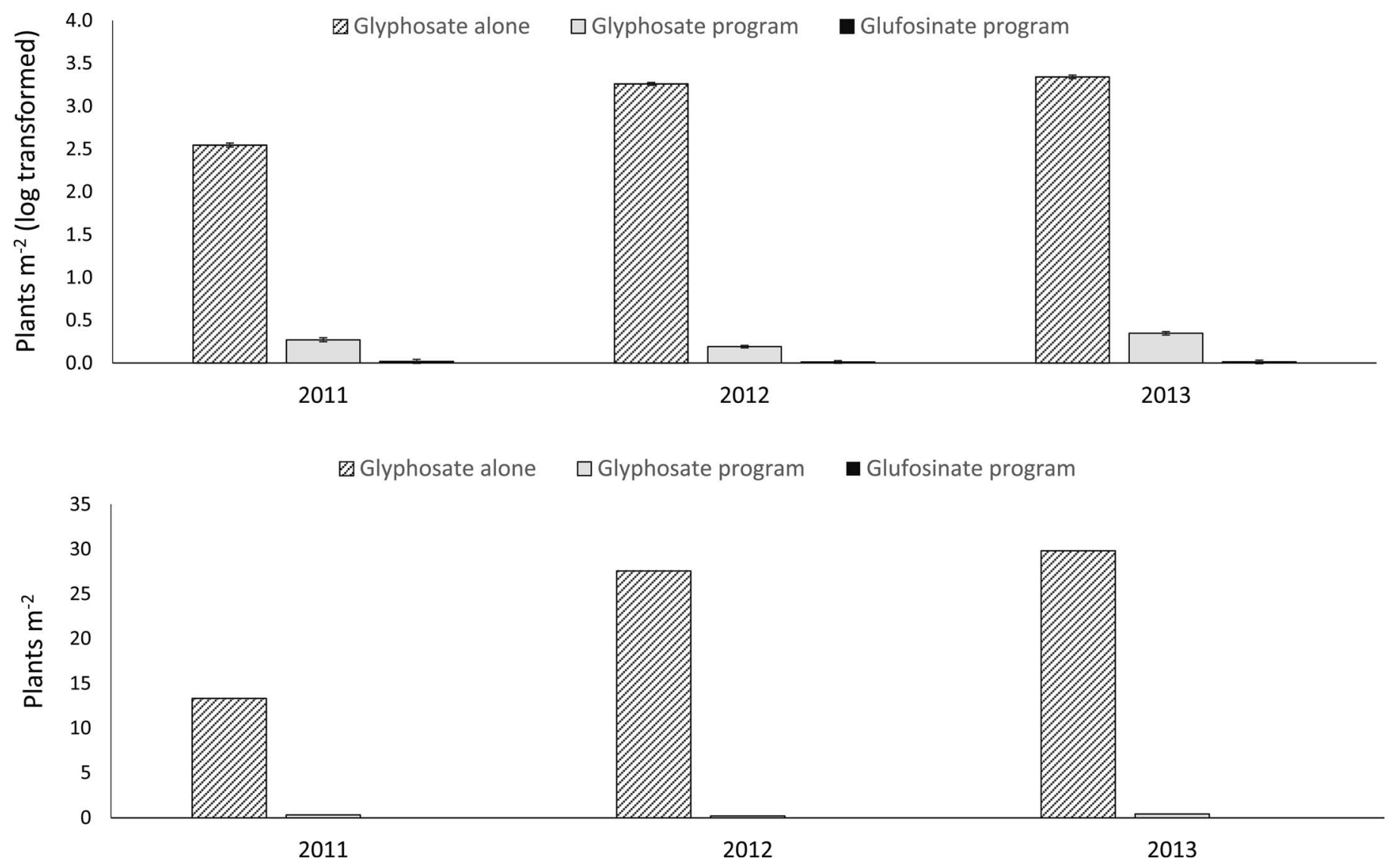

Figure 1. Effects of herbicide program on the untransformed Palmer amaranth density data averaged over fall management practices. The vertical bars represent the standard error of the transformed Palmer amaranth seed production mean values.

al. 2014). However, where infestations of glyphosate-resistant Palmer amaranth occur, alternative sites of action (SOA) or weed management strategies must be sought (Neve et al. 2011; Whitaker et al. 2010). The inclusion of PRE herbicides with alternate SOA in addition to glyphosate into the herbicide program resulted in large $(\alpha=0.05)$ reductions in Palmer amaranth population densities (Table 2 ) and subsequent seed production compared to the glyphosate-only herbicide program each year of the study (Figure 1). In particular, reductions in Palmer amaranth seed production due to inclusion of a PRE application into the herbicide program ranged from 97 to 99.9\% compared to those obtained when glyphosate was applied alone (Figure 1).

Glufosinate plus PRE herbicide treatments consistently provided excellent control of Palmer amaranth population densities and seed production. In comparison to glyphosate alone, reductions of up to $99.9 \%$ of Palmer amaranth plant density and seed production were observed in each year of the trial (Figures 1 and 2). The consistency in the effects of the PRE $\mathrm{fb}$ POST herbicide program treatments on both Palmer amaranth parameters measured highlights the potential for using alternate herbicides to control glyphosate-resistant Palmer amaranth in soybean.

Interaction of Fall Management Practices with Herbicide Programs. The most effective means of preventing the evolution of herbicide resistance is through the diversification of weed management programs by combining herbicides with different SOAs and incorporating nonchemical control tools (Norsworthy et al. 2012). A multiple-tactic approach consisting of preventive, cultural, and chemical methods is necessary for long-term management of Palmer amaranth (Chahal et al. 2015; Harker and O'Donovan 2013). The beneficial effects of cover crops (Korres and Norsworthy 2015; Kruidhof et al. 2008), HWSC practices (Walsh and Newman 2007; Walsh and Powles 2007), tillage (Culpepper et al. 2010), and herbicide use on weed control have been reported extensively. However, some sets of management practices are complimentary, whereas others are not; hence, a multitactical management strategy would ideally be comprised of combinations of weed management

Norsworthy et al.: Management practices influence Palmer amaranth dynamics • 545 

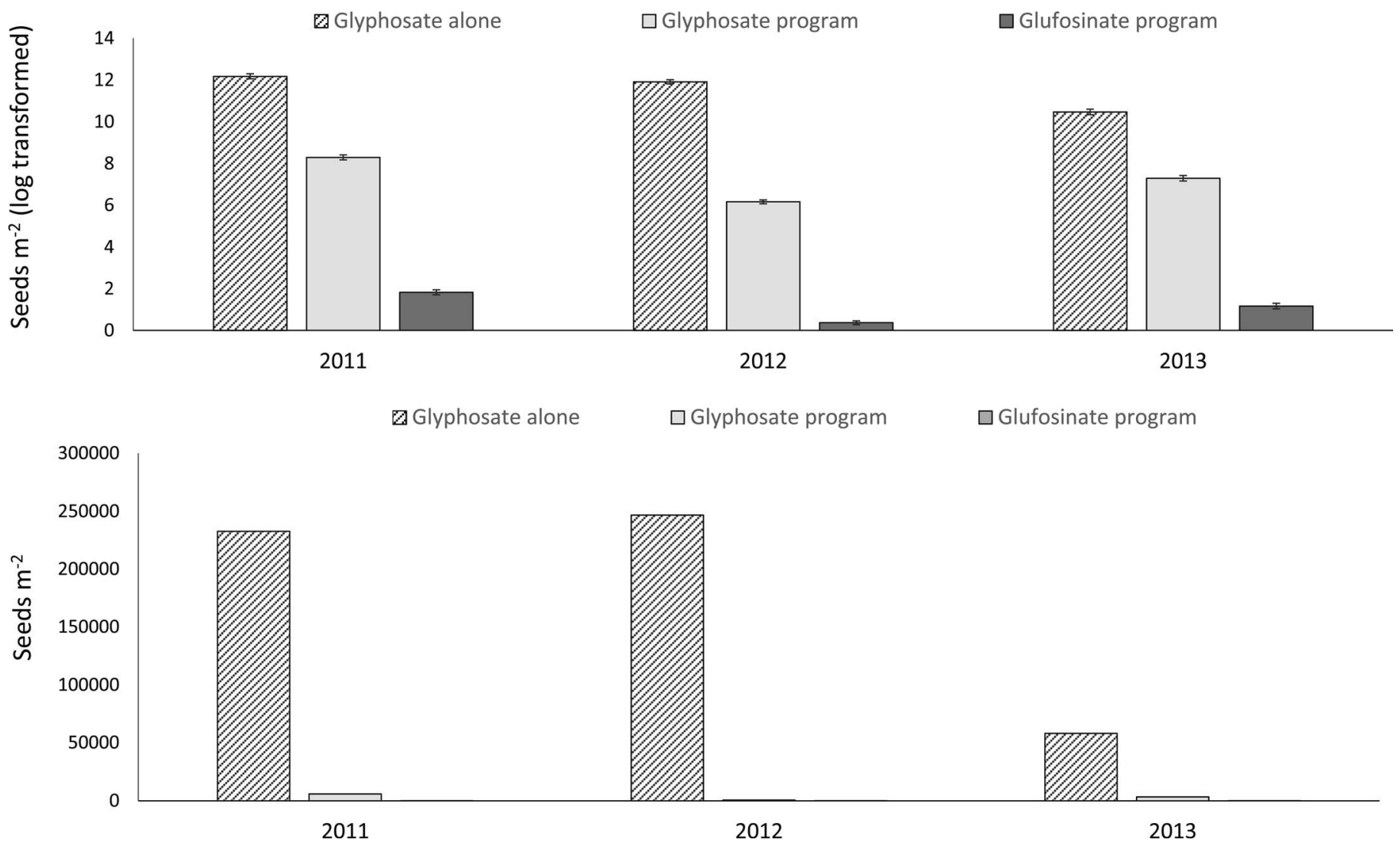

Figure 2. Effects of herbicide program on the untransformed Palmer amaranth seed production data averaged over fall management practices. The enclosed figures were developed based on the outcome of the log-transformed data analysis. The vertical bars represent the standard error of the transformed Palmer amaranth seed production mean values.

practices that result in interactions that are synergistic or at least additive in nature.

Results presented in this study indicate that the adoption of appropriate fall management practices accompanied by justified herbicide treatments can significantly reduce the population density of glyphosate-resistant Palmer amaranth. PRE $\mathrm{fb}$ POST herbicides resulted in significant decreases in the Palmer amaranth population density $(\alpha=0.001)$ (Table 3$)$ and seed production $(\alpha=0.01$ to 0.05$)$ (Table 4$)$ compared to POST application of glyphosate alone for all fall management practices tested. The addition of a PRE herbicide into the programs caused an interaction between herbicide regimes and fall management practices. For instance, in the glyphosate-only system, narrow-windrow burning reduced Palmer amaranth density each year, but the addition of a PRE herbicide to the program masked the effect of this practice compared to narrow-windrow without burning (Table 3).

In-situ stubble burning along with conventional tillage are methods traditionally used in an attempt to destroy weed seed or limit weed seed inputs into the soil seedbank (Anonymous, undated; Walsh and Powles 2007). Nonetheless, the environmental friendliness of these traditional methods, particularly in situ residue burning, has been questioned (Anonymous, undated). Although the strategic application of burning and conventional tillage in conjunction with other management strategies are common in some geographies, these combined strategies can be quite effective in reducing viable weed seed number, especially in soils with low erosion potential (Holding et al. 2014).

The transformation of the effectiveness of no-till practice on Palmer amaranth population density and seed production (Tables 3 and 4, respectively) by the incorporation of PRE herbicide application and parallel substitution of glyphosate by glufosinate is remarkable. Reductions up to $99.9 \%$ in comparison to a glyphosate-only program were obtained for both Palmer amaranth parameters and for each year of the experiment. Conservation tillage can improve soil fertility and reduce soil erosion/ runoff, but often involves the use of more herbicides (Armengot et al. 2015; Bates et al. 2012). Nevertheless, the limited availability of POST 
Table 4. Influence of fall management practices and herbicide programs in soybean on Palmer amaranth seed production in the fall of 2011, 2012, and 2013 at Keiser, AR. Experimental treatments for fall management practices were initiated fall of 2010, and herbicide programs were initiated spring of 2011 with each practice and program applied to the same plots each year through fall of 2013.

\begin{tabular}{|c|c|c|c|c|}
\hline Fall management practice ${ }^{a}$ & Herbicide program $^{\mathrm{b}}$ & 2011 & 2012 & 2013 \\
\hline & & & - seeds $\mathrm{m}^{-2}$ & \\
\hline \multirow{3}{*}{ No-till (standard) } & Glyphosate-only & $407,000(12.9)^{\mathrm{c}}$ & $189,000(12.1)^{\mathrm{c}}$ & $101,000(11.5)$ \\
\hline & Glyphosate + residuals & $2,720(7.90)$ & $978(6.9)$ & $515(6.2)$ \\
\hline & Glufosinate + residuals & $5.5(1.7)$ & $0.0(0.0)$ & $0.0(0.0)$ \\
\hline \multirow[t]{3}{*}{ Fall tillage } & Glyphosate-only & $199,000(12.2)$ & $149,000(11.9)$ & $150,000(11.9)$ \\
\hline & Glyphosate + residuals & $15,400(9.6)$ & $359(5.9)$ & $8,480(9.0)$ \\
\hline & Glufosinate + residuals & $11(2.4)$ & $9.2(2.2)$ & $73.8(4.3)$ \\
\hline \multirow[t]{3}{*}{ Rye cover crop } & Glyphosate-only & $300,000(12.6)$ & $65,400(11.1)$ & $31,500(10.3)$ \\
\hline & Glyphosate + residuals & $6,010(8.7)$ & $307(5.7)$ & $131(4.9)$ \\
\hline & Glufosinate + residuals & $2.2(0.8)$ & $1.0(0.0)$ & $1.0(0.0)$ \\
\hline \multirow[t]{3}{*}{ Narrow windrow without burning } & Glyphosate-only & $167,000(12.0)$ & $466,000(13.0)$ & $14,200(9.5)$ \\
\hline & Glyphosate + residuals & $3,420(8.1)$ & $459(6.1)$ & $4,180(8.3)$ \\
\hline & Glufosinate + residuals & $7.0(1.9)$ & $1.0(0.0)$ & $8.3(2.1)$ \\
\hline \multirow{3}{*}{ Narrow windrow with burning } & Glyphosate-only & $104,000(11.5)$ & $101,000(11.6)$ & $20,900(9.9)$ \\
\hline & Glyphosate + residuals & $2,510(7.8)$ & $473(6.1)$ & $4,140(8.3)$ \\
\hline & Glufosinate + residuals & $11.2(2.4)$ & $1.0(0.00)$ & $2.1(0.0)$ \\
\hline \multirow[t]{3}{*}{ Residue collection and removal } & Glyphosate-only & $122,000(11.6)$ & $126,000(11.8)$ & $14,100(9.5)$ \\
\hline & Glyphosate + residuals & $1,850(7.5)$ & $480(6.2)$ & $988(6.9)$ \\
\hline & Glufosinate + residuals & $5.8(1.7)$ & $1.0(0.00)$ & $1.8(0.6)$ \\
\hline Standard error of transformed mean ${ }^{\mathrm{d}}$ & & 0.43 & 0.39 & 0.49 \\
\hline
\end{tabular}

${ }^{a}$ Refer to the Materials and Methods section for a thorough description of each fall management practice.

b The glyphosate-only program consisted of sequential glyphosate applications at $870 \mathrm{~g}$ ae ha ${ }^{-1}$ at $\mathrm{V} 2$ and $\mathrm{V} 7$ stage of soybean. The glyphosate + residual program consisted of flumioxazin at $71 \mathrm{~g}$ ai ha ${ }^{-1}$ PRE followed by (fb) glyphosate at $870 \mathrm{~g} \mathrm{ha}^{-1}+S$ metolachlor at $1,215 \mathrm{~g}$ ai ha $^{-1}$ and fomesafen at $266 \mathrm{~g}$ ai ha ${ }^{-1}$ at V2 stage of soybean fb glyphosate at $870 \mathrm{~g} \mathrm{ha}^{-1}$ at V7 stage of soybean. The glufosinate + residual program was the same as the glyphosate + residual program, except both glyphosate applications were replaced with glufosinate at $594 \mathrm{~g}$ ai ha ${ }^{-1}$.

${ }^{c}$ Parentheses contain the mean for natural log-transformed data $(1+$ plot data).

${ }^{\mathrm{d}}$ Standard error of mean is for natural log-transformed data $(1+$ plot data $)$ and can be used to assess differences between treatments.

herbicide SOAs due to evolved herbicide resistance in combination with the low soil disturbance by the adoption of conservation tillage can increase the weed populations and cause shifts in the weed spectrum (Beckie et al. 2008; Owen 2008).

The incorporation of both PRE and POST herbicides into the system can reduce the selection pressure associated with sole reliance on POST herbicide applications, particularly when glyphosate-resistance has evolved as in the case of some of the most agronomically important weed species such as ragweed (Ambrosia spp.), horseweed (Conyza spp.), ryegrass (Lolium spp.) and johnsongrass [Sorghum halepense (L.) Pers.] including Palmer amaranth (Heap 2016). In addition, the incorporation of PRE and POST herbicides could strengthen the effectiveness of cropping systems that promote a reduction in tillage, especially in light of the fact that glyphosate-resistant Palmer amaranth currently threatens the sustainability of conservation tillage in many geographies (Price et al. 2011).
The effects of rye cover crop on Palmer amaranth parameters, in this study, were enhanced with the PRE herbicide application and substitution of glyphosate by glufosinate (Tables 3 and 4). This is in agreement with Culpepper et al. (2010) who showed that the employment of rye as a cover crop increased Palmer amaranth control 18\% when used in conjunction with a glufosinate-based cotton herbicide program.

Soybean Yield. Soybean yield averaged across herbicide programs was affected $(\alpha=0.05)$ by fall management practices with "no till," "narrow windrowing without burning," and "residue collection and removal" exhibiting, in most occasions, lower yields compared to other practices (Table 5). Likewise, the effects of herbicide program on soybean yield averaged among fall management treatments were inconsistent with glyphosate-only and glufosinate + residual programs exhibiting lower yields in comparison to glyphosate + residual in 2011 and 2013 (Table 6). Differences in soybean yield may be attributed to cultivar selection (i.e.,

Norsworthy et al.: Management practices influence Palmer amaranth dynamics • 547 
Table 5. Effects of fall management practices on soybean yield $\left(\mathrm{kg} \mathrm{ha}^{-1}\right)$ averaged across all herbicide treatments.

\begin{tabular}{lccc}
\hline Fall management practice $^{\mathrm{a}}$ & 2011 & 2012 & 2013 \\
\hline No till (standard) & 3,552 & 4,568 & 3,235 \\
Fall tillage & 3,731 & 4,591 & 3,500 \\
Rye cover crop & 3,698 & 4,180 & 3,067 \\
Windrowing with burning & 3,726 & 4,618 & 3,112 \\
Windrowing without burning & 3,529 & 4,440 & 2,970 \\
Residue collection and removal & 3,182 & 4,277 & 3,061 \\
Standard error of mean & 116.6 & 99.5 & 136.7 \\
\hline
\end{tabular}

${ }^{a}$ Refer to the Materials and Methods section for a thorough description of each fall management practice.

more than one soybean cultivar grown each year) as soybean yields are closely related to genetic potential (Scaboo et al. 2010).

Practical Implications. Fall management practices are a useful preventive tool against weeds that should be considered for inclusion in weed management programs. Farmers should broaden and diversify their weed control options by incorporating HWSC strategies that target Palmer amaranth escapes at crop harvest or integrate a fall planted cover crop into current production systems; ultimately reducing the soil seedbank and the risk for new cases of herbicide resistance evolving. This research also points to the strength of glufosinatebased weed control programs on glyphosate-resistant Palmer amaranth and the fact that integration with a successful fall management practice will help lower weed seedbanks. Use of narrow-windrow burning, when conditions are suitable, can be integrated into current soybean production systems and is a low-cost and efficient means of protecting against further evolution of herbicide resistance.

This study demonstrated that fall management practices such as residue removal from the harvester, the use of cover crops, or in most circumstances burning narrow-windrowed soybean residues in combination with an effective PRE $\mathrm{fb}$ POST residual herbicide program is an important management tool in reducing the Palmer amaranth population density and seed production (Tables 3 and 4). It is clear that herbicides with differing SOAs remain the most efficient tool for the control of glyphosate-resistant Palmer amaranth. However, the continued increase in evolved herbicide resistance in prominent weed species must lead to changes in the way herbicides are currently used and viewed. Herbicides are a precious resource that are in limited supply and greater emphasis needs to be placed on targeting weed seed production. Such attempts to prevent inputs to the seedbank is of
Table 6. Effects of herbicide program ${ }^{\mathrm{a}}$ on Palmer amaranth yield $\left(\mathrm{kg} \mathrm{ha}^{-1}\right)$ averaged across all fall management practices.

\begin{tabular}{lccc}
\hline & 2011 & 2012 & 2013 \\
\hline Glyphosate-only & 3,451 & 4,312 & 3,057 \\
Glyphosate + residuals & 3,766 & 4,455 & 3,366 \\
Glufosinate + residuals & 3,492 & 4,569 & 3,099 \\
Standard error of mean & 64.7 & 54.5 & 84.4 \\
\hline
\end{tabular}

${ }^{a}$ Refer to the Materials and Methods section for a thorough description of each herbicide treatment.

primary importance in the management of Palmer amaranth in addition to maximizing the useful life of herbicides for its control.

\section{Acknowledgments}

Support for this research from the Arkansas Soybean Promotion Board and from Bayer CropScience is gratefully appreciated.

\section{Literature Cited}

Akemo MC, Regnier EE, Bennett MA (2000) Weed suppression in spring-sown rye (Secale cereale) pea (Pisum sativum) cover crop mixes. Weed Technol 14:545-549

Amuri N, Brye KR, Gbur EE, Oliver D, Kelley J (2010) Weed populations as affected by residue management practices in a wheat-soybean double-crop production system. Weed Sci 58:234-243

Anonymous (undated) Managing downy brome under conservation tillage systems in the Northwest cropping region. In Pacific Northwest Conservation Tillage Handbook. A Pacific Northwest Cooperative Extension Publication, Washington, Oregon, Idaho. http://pnwsteep.wsu.edu/tillagehandbook/ chapter5/pnw0509.htm. Accessed December 16, 2015

Armengot L, Berner A, Blanco-Moreno J, Mader P, Sans FX (2015) Long-term feasibility of reduced tillage in organic farming. Agron Sustain Dev 35:339-346

Bates RT, Gallagher RS, Curran WS, Harper JK (2012) Integrating mechanical and reduced chemical weed control in conservation tillage corn. Agron J 104:507-517

Beckie HJ, Leeson JY, Thomas AG, Hall LM, Brenzil CA (2008) Risk assessment of weed resistance in the Canadian prairies. Weed Technol 22:741-746

Blackshaw RE, Moyer JR, Doram RC, Bosweell AL (2001) Yellow sweet clover, green manure, and its residues effectively suppress weed during fallow. Weed Sci 49:406-413

Bryson CT, Hanks JE (2006) Weed Populations in Conventional and Conservation Tillage Management Cotton and Soybean Systems. Mississippi Agricultural \& Forestry Experiment Station, Research Report Vol. 23, No. 18. Stoneville, MS: Mississippi State University. 5p

Chahal PS, Aulakh JS, Jugulam M, Jhala AJ (2015) Herbicideresistant Palmer amaranth (Amaranthus palmeri S. Wats.) in the United States: mechanisms of resistance, impact, and management. Pages 1-29 in Price A, Kelton J, Sarunaite L eds. Herbicides, Agronomic Crops and Weed Biology. Rijeka, Croatia: InTech 
Chauhan BS, Abugho SB (2013) Effect of crop residue on seedling emergence and growth of selected weed species in a sprinkler-irrigated zero-till dry-seeded rice system. Weed Sci 61:403-409

Crow WD, Steckel LE, Hayes RM, Mueller TC (2015) Evaluation of POST-harvest herbicide applications for seed prevention of glyphosate-resistant Palmer amaranth (Amaranthus palmeri). Weed Technol 29:405-411

Culpepper AS, Kichler J, Sosnoskie L, York A, Sammons D, Nichols B (2010) Integrating cover crop residue and moldboard plowing into glyphosate-resistant Palmer amaranth management programs. In Proceedings of the 2010 Beltwide Cotton Conference. Cordova, TN: National Cotton Council of America. $1531 \mathrm{p}$

Devenish KL, Leaver LJ (2000) The fate of ryegrass seed when sheep graze chaff cart heaps. Asian-Aus J Anim Sci 13 (Suppl):484. Available at: http://www.asap.asn.au/ livestocklibrary/2000/Devenish_0631.pdf. Accessed March 15,2016

DeVore JD, Norsworthy JK, Brye KR (2013) Influence of deep tillage, a rye cover crop, and various soybean production systems on Palmer amaranth emergence in soybean. Weed Technol 27:263-270

Fogelfors H (1982) Collection of chaff, awns and straw when combining and its influence on the seed bank and the composition of the weed flora. Pages 339-345 in Weeds and Weed Control: 23rd Swedish Weed Conference. Uppsala, Sweden: Department of Plant Husbandry and Research Information Centre, Swedish University of Agricultural Science

Haramoto ER, Gallandt ER (2004) Brassica cover cropping for weed management: a review. Renew Agr Food Syst 19:187198

Harker KN, O’Donovan JT (2013) Recent weed control, weed management, and integrated weed management. Weed Technol 27:1-11

Heap I (2016) The international survey of herbicide resistant weeds. http://www.weedscience.org. Accessed March 15, 2016

Holding D, Lemerle D, Stewart V, Walsh M (2014) Tactics for managing weed populations (Section 4). Pages 31-235 in Storrie AM, ed. Integrated Weed Management in Australian Cropping Systems. Canberra, Australia: Grains Research and Development Corporation

Kleemann S, Preston C, Gill G (undated) Harvest Weed Seed Control: Narrow Windrow Burning. The University of Adelaide, Hart Field-Site Group. http://www.hartfieldsite. org.au/media/2014\%20Trial\%20Results/2014_Results_ Harvest_weed_seed_control_narrow_windrow_burning.pdf. Accessed March 24, 2016

Klingaman TE, Oliver LR (1994) Palmer amaranth (Amaranthus palmeri) interference in soybeans (Glycine max). Weed Sci 42:523-527

Korres NE, Froud-Williams RJ (2002) Effects of winter wheat cultivars and seed rate on the biological characteristics of naturally occurring weed flora. Weed Res 42:417-428

Korres NE, Norsworthy JK (2015) Influence of a rye cover crop on the critical period for weed control in cotton. Weed Sci 63:346-352

Kruidhof HM, Bastiaans L, Kropff MJ (2008) Ecological weed management by cover cropping: effects on weed growth in autumn and weed establishment in spring. Weed Res 48:492502
Liebl R, Simmons FW, Wax LM, Stoller EW (1992) Effects of rye (Secale cereale) mulch on weed control and soil moisture in soybean (Glycine max). Weed Technol 6:838-846

Massinga RA, Currie R, Horak MJ, Boyer Jr J (2001) Interference of Palmer amaranth in corn. Weed Sci 49:202208

Morgan GD, Bauman PA, Chandler JM (2001) Competitive impact of Palmer Amaranth (Amaranthus palmeri) on cotton (Gossypium hirsutum) development and yield. Weed Technol 15:408-412

Neve P, Norsworthy JK, Smith KL, Zelaya IA (2011) Modelling glyphosate resistance management strategies for Palmer amaranth in cotton. Weed Technol 25:335-343

Neyman JS, Dabrowska DM, Speed TP (1990) On the application of probability theory to agricultural experiments. Essay on principles. Section 9. Statistical Sci 5:332-338

Norsworthy JK, Griffith G, Griffin T, Gbur EE (2014) In-field movement of glyphosate-resistant Palmer amaranth (Amaranthus palmeri) and its impact on cotton lint yield: evidence for a zero threshold. Weed Sci 62:237-249

Norsworthy JK, Ward SM, Shaw DR, Llewellyn RS, Nichols RL, Webster TM, Bradley KW, Frisvold G, Powles SB, Burgos NR, Witt WW, Barrett M (2012) Reducing the risks of herbicide resistance: best management practices and recommendations. Weed Sci (Special Issue) 60:31-62

Owen MDK (2008) Weed species shifts in glyphosate-resistant crops. Pest Manag Sci 64:377-387

Price AJ, Balkcom KS, Culpepper SA, Kelton JA, Nichols RL, Schomberg H (2011) Glyphosate-resistant Palmer amaranth: a threat to conservation tillage. J Soil Water Conserv 66:265275

Rankins A Jr, Byrd JD Jr, Mask DB, Barnett JW, Gerard PD (2005) Survey of soybean weeds in Mississippi. Weed Technol 19:492-498

Reed JD, Keeling JW, Dotray PA (2014) Palmer amaranth (Amaranthus palmeri) management in GlyTol LibertyLink cotton. Weed Technol 28:592-600

Riar DS, Norsworthy JK, Steckel LE, Stephenson DO, Bond JA (2013a) Consultant perspectives on weed management needs in Midsouthern United States cotton: a following-up survey. Weed Technol 27:778-787

Riar DS, Norsworthy JK, Steckel LE, Stephenson DO, Eubank TW, Scott RC (2013b) Assessment of weed management practices and problem weeds in the Midsouth United States soybean: a consultant's perspective. Weed Technol 27:612622

Rowland MW, Murray DS, Verhalen LM (1999) Full-season Palmer amaranth (Amaranthus palmeri) interference with cotton (Gossypium hirsutum). Weed Sci 47:305-309

Scaboo AM, Chen P, Sleper DA, Clark KM (2010) Classical breeding and genetics of soybean. Pages 19-55 in Bilyeu K, Ratnaparkhe MB, Kole C, eds. Genetics, Genomics and Breeding of Soybean. Series on Genetics, Genomics and Breeding of Crop Plants. Boca Raton, FL: CRC Press

Schomberg HH, McDaniel RG, Mallard E, Endale DM, Fisher DS, Cabrera ML (2006) Conservation tillage and cover crop influences on cotton production on a southeastern U.S. coastal plain soil. Agron J 98:1247-1256

Schwartz LM, Norsworthy JK, Young BG, Bradley KW, Kruger GR, Davis VM, Steckel LE, Walsh MJ (2016) Waterhemp (Amaranthus tuberculatus) and Palmer amaranth (Amaranthus

Norsworthy et al.: Management practices influence Palmer amaranth dynamics • 549 
palmeri) seed production and retention at soybean harvest. Weed Technol 30:284-290

Shirtliffe SJ, Entz MH (2005) Chaff collection reduces seed dispersal of wild oat (Avena fatua) by a combine harvester. Weed Sci 53:465-470

Skroch WA, Powell MA, Bilderback TE, Henry PH (1992) Mulches: durability, aesthetic value, weed control and temperature. J Environ Hort 10:43-45

Sparks OC, Barrentine JL, Burgos NR, McClelland MR (2003) Effect of Palmer amaranth (Amaranthus palmeri) seedbank density on the performance of pendimethalin and fluometuron. Summaries of Arkansas Cotton Research 2003. AAES Research Series 521:167-172

Storrie AM, ed (2014) Integrated Weed Management in Australian Cropping Systems. Canberra, Australia: Grains Research and Development Corporation. 386 p

Teasdale JR (1996) Contribution of cover crops to weed management in sustainable systems. J Prod Agric 9:475-479

Teasdale JR, Mohler CL (1993) Light transmittance, soil temperature, and soil moisture under residue of hairy vetch and rye. Agron J 85:673-680

Walsh MJ, Newman P (2007) Burning narrow windrows for weed seed destruction. Field Crops Res 104:24-30
Walsh MJ, Newman P, Powles SB (2013) Targeting weed seeds in-crop: a new weed control paradigm for global agriculture. Weed Technol 27:431-436

Walsh MJ, Powles SB (2004) Herbicide resistance: an imperative for smarter crop weed management. Pages 1-6 in Proceedings of the 4th International Crop Science Congress. Brisbane, Australia: The Regional Institute Ltd

Walsh MJ, Powles SB (2007) Management strategies for herbicide-resistant weed populations in Australian dryland crop production systems. Weed Technol 21:332-338

Ward SM, Webster TM, Steckel LE (2013) Palmer amaranth (Amaranthus palmeri): a review. Weed Technol 27:12-27

Watson GW (1988) Organic mulch and grass competition influence tree root development. J Arboriculture 14:200-203

Whitaker JR, York AC, Jordan DL, Culpepper AS (2010) Palmer amaranth (Amaranthus palmeri) control in soybean with glyphosate and conventional herbicide systems. Weed Technol 24:403-410

Received December 23, 2015, and approved April 6, 2016.

Associate Editor for this paper: Chris Preston, University of Adelaide. 